UDC 616.22-002-008.5-057:37.011.3-051]-084

https://doi.org/10.26641/2307-0404.2020.3.214858

\section{I.V. Savushina ${ }^{1}$, O.I. Pavlenko ${ }^{1}$, Y.V. Zos'ka ${ }^{2}$}

\title{
PREVENTION OF OCCUPATIONAL \\ LARYNGITIS IN TEACHERS
}

SI "Ukrainian Scientific and Research Institute of Industrial Medicine" 1

Vinohradova str., 40, Kryvyi Rih, Dnipropetrovsk Region, 50096, Ukraine

e-mail: ilonalinfo@gmail.com

Classical private university ${ }^{2}$

Zhukovskoho str., 70 b, Zaporizhzhia, 69002, Ukraine

e-mail: zoskayana@gmail.com

ДУ «Украӥнський науково-дослідний інститут промислової медицини» ${ }^{1}$

вул. Виноградова, 40, Кривий Ріг, Дніпропетровська область, 50096, Украӥна

Класичний приватний університет ${ }^{2}$

вул. Жуковського, 70б, Запоріжжя, 69002, Україна

Цитування: Медичні перспективи. 2020. T. 25, № 3. С. 161-168

Cited: Medicni perspektivi. 2020;25(3):161-168

Key words: working conditions of teachers, morbidity of teachers, chronic laryngitis, voce load, prevention of occupational laryngitis, therapy of occupational laryngitis

Ключові слова: умови прачі вчителів, захворюваність вчителів, хронічний ларингіт, голосове навантаження, профілактика професійного ларингіту, лікування професійного ларингіту

Ключевые слова: условия труда учителей, заболеваемость учителей, хронический ларингит, голосовые нагрузки, профилактика профессионального ларингита, лечение профессионального ларингита

\begin{abstract}
Prevention of occupational laryngitis in teachers. Savushina I.V., Pavlenko O.I., Zos'ka Y.V. The number of people in need of phoniatric help is constantly increasing. People with voice problems are of working age. The object of researche: lowering risk of progression of vocal pathology based on a comprehensive system of management of teachers' occupational risks. Hygienic, epidemiological, sanitary-statistical, in-depth medical examination method and mathematical-statistical methods were applied. Working conditions of teachers are characterized by complex effects of harmful production factors, which can reach $3^{d}$ degree of $3^{d}$ class of harmful work by intensity (according to the calculated points 3,63), 2nd degree of $3^{d}$ class of harmful pressure on vocal apparatus (27,52 $\pm 3,54$ hours), $1^{\text {st }}$ degree of $3^{d}$ class of harmful by equivalent noise level and unfavorable microclimate. The most widespread pathologies of the vocal apparatus are chronic hypertrophic laryngitis $(190,20 \pm 22,61)$ and chronic

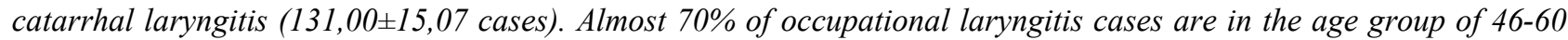
years. The critical length of service influenced by voice load is 10-19 years. The length of service more than 20 years in conditions of voice load increases the etiological percent of occupational pathology causes to 81,8\%. Therefore, an age of 45,8 $\pm 0,5$ and older is dangerous for the occupational laryngitis progression and requires a special approach of development and implementation of preventive measures aimed at maintaining of occupational health. Suggested complex of measures increase the healthy life by 7,3 years and reduce the loss of healthy life years determined by the impact of voice activity by 7,1 years. At the same time for physical health component (PH) by 4,5 and 4,3, and the psychological health component $(\mathrm{MH})$ by 10,3 and 10,1 years QALY respectively.
\end{abstract}

Реферат. Профілактика професійного ларингіту у вчителів. Савушина І.В., Павленко О.І., Зоська Я.В. Коло осіб, які потребують фоніатричної допомоги, у наш час постійно збільшується. Люди з патологією голосу перебувають у працездатному віці. Метою досліджень було: зниження ризику розвитку професійної патологї голосового апарату на підставі обтрунтування комплексної системи керування професійним ризиком у вчителів. Під час досліджень був застосований гігієнічний, епідеміологічний, санітарно-статистичний метод поглибленого медичного обстеження та математико-статистичний метод. Умови праці вчителів характеризуються комплексним впливом шкідливих виробничих факторів, які можуть досягати 3 ступеня 3 класу шкідливого за напруженістю пращі (згідно з розрахованими балами 3,63), 2 ступеня 3 класу шкідливого за

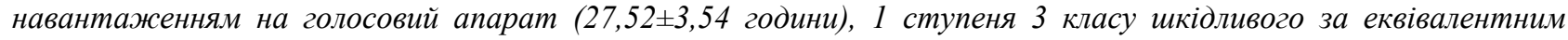
рівнем шуму та несприятливим мікрокліматом. Найбільш розповсюдженою патологією голосового апарату у вчителів є хронічний гіпертрофічний ларингіт $(190,20 \pm 22,61)$ та хронічний катаральний ларингіт

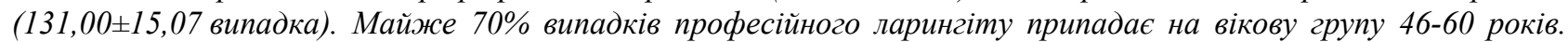


Критичним стажем роботи в умовах впливу голосового навантаження є 10-19 років. Стаж роботи понад 20 років в умовах голосового навантаження збільшує етіологічну частку в причинах виникнення професійної

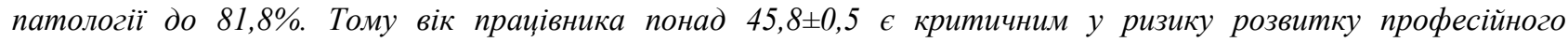
захворювання, щз потребує особливого підходу при розробиі та впровадженні профілактичних заходів, спрямованих на збереження професійного здоров'я. Запропонований комплекс заходів збільшить здорову частку життя на 7,3 року $і$ зменшить втрати років здорового життя на 7,1 року, в тому числі для фізичного компоненту здоров'я (РН) на 4,5 і 4,3 і психологічного компоненту здоров'я (MH) на 10,3, 10,1 років QАLY відповідно.

The problem of the occupational health of teachers in Ukraine is currently underestimated $[1,5$, 12]. Although the national doctrine of educational development determines the accelerated, proactive and innovate educational development in the first quarter of the $21^{\text {st }}$ century, which, accordingly, will increase the risk of occupational pathology of teachers [4]. This problem is not unique to Ukraine, but is being developed by scientists all over the world $[7,8,10,11]$.

The number of people in need of phoniatric help is constantly increasing. These include professional actors, singers, radio and television announcers, teachers, and service workers [2,9].

People with voice problems are of working age (20-60 years), so voice rehabilitation is socially important to them $[1,3,6]$.

Despite the number of scientific researches, the least studied question is lowering risk of progression of voce pathology based on a comprehensive system of management of teachers' occupational risks, which was determined as an object of research.

\section{MATERIALS AND METHODS OF RESEARCH}

Hygienic, epidemiological, sanitary-statistical, in-depth medical examination method and mathematical-statistical methods were applied in the research. The stages and scope of the research are shown in Figure 1.

The study and evaluation of conditions were performed by classical hygienic methods. The likelihood of occupational laryngitis was calculated according to a standard methodology for determining risk (Izmer N.F., Denisov E.I., 2003), based on the analysis of ambulatory charts of 63 teachers with voice apparatus disease associated with working conditions. The health of 93 teachers was assessed by determining the level of features of functioning of the circulatory system and the adaptive capacity of the whole organism according to the formula (Bayevsky et al., 1987). To identify and evaluate the risks of occupational pathology, an international methodology was applied (Murtonen M., 2004; Kalkis V., 2005). Standard DALY methodology was used to determine the effectiveness of the proposed measures (Homedes N., 1996).
To determine the statistical significance of the differences in the characteristics of the investigated independent samples with normal distribution, the parametric criterion t-student test for independent samples was used. In the case of distribution other than normal, the nonparametric Mann-Whitney test was used. Statistical processing of the material was performed using IBM's SPSS 20.0 software for Windows i Microsoft Excel 2003 (N HK9TK-GB4KD3936D-8R6C8-DJTHD) та STATISTICA 6.0. (N 31415-9265-35897).

\section{RESULTS AND DISCUSSION}

Working conditions of teachers in general educational institutions. Work of teacher belongs to the $2^{\text {nd }}$ class of allowable by severity indicators (working position "standing", forced bending of the trunk more than $30^{\circ}$ ), and it belongs to $3^{\mathrm{d}}$ degree of $3^{\mathrm{d}}$ class of harm by indicators of intensity (according to calculated points 3,63 ) according to Order N 248 of 08.04.2014 DSN-P «Hygienic classification of labor by indicators of harm and danger of industrial environment, severity and intensity of labor process»».

The microclimate parameters of the teachers' workplace, both in the warm and cold year periods very greatly, which is related to the cabinet location (floor, corner office, the location of windows), the presence or absence of central heating and belong to $1^{\text {st }}$ degree $3^{\mathrm{d}}$ class of harm.

While writing the materials on the blackboard, or in the case of wiping the board with a dry cloth, a dust cloud with calcium carbonate content may form, which is part of school chalk at a concentration of $0.012 \mathrm{mg} / \mathrm{m}^{3}$ to $0.068 \mathrm{mg} / \mathrm{m}^{3}$ with an average of $0.03 \pm 0.00 \mathrm{mg} / \mathrm{m}^{3}$ at the normative level $0.05 \mathrm{mg} / \mathrm{m}^{3}$, which belongs to $2^{\text {nd }}$ class of allowable.

Equivalent level of noise at the workplace of scientific-natural lyceum teacher exceeds the allowable level by $35 \mathrm{~dB}$, which refers to the $1^{\text {st }}$ degree of the $3^{\mathrm{d}}$ class of harm.

As result of the study of sanitary and microbiological parameters of the working area air in the classroom, it was found that during the shift the total microbial number gradually increases from $569.33 \pm 174.55$ microorganisms in a time from $8.00-8.30$ to $2333.33 \pm 209.13$ microorganisms at $14.15-14.45$, but 
it does not exceed the requirements of sanitary standards (4500 microorganisms $/ \mathrm{m}^{3}$ ). Thus, there is gradual air pollution (during the work shift) of the teacher's working area with bacteria.
Summing up, working conditions of a secondary school teacher belongs to $3^{\mathrm{d}}$ degree of $3^{\mathrm{d}}$ class of harm according to general hygienic assessment (table 1).

Stage I - sanitary and hygienic studies of working conditions of teachers of general educational institutions in Kryvyi Rih
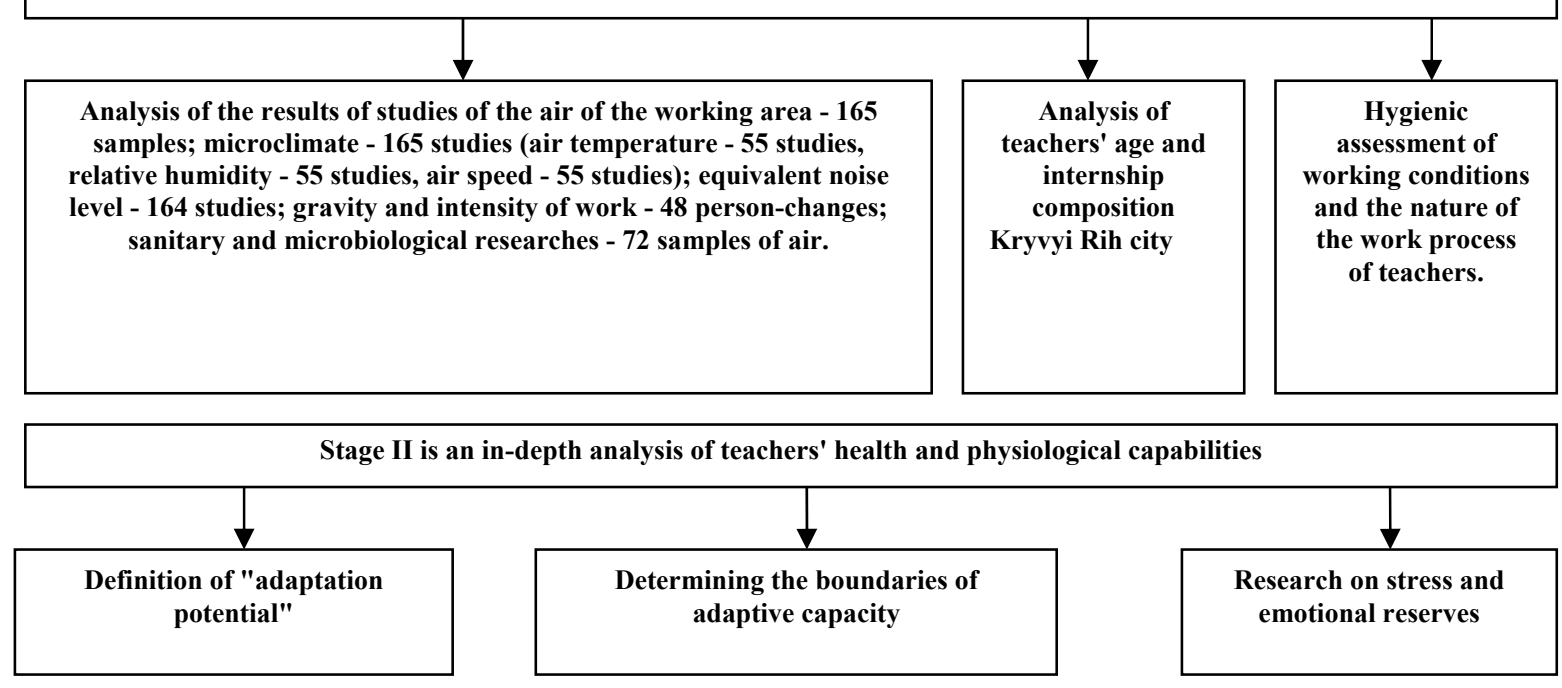

Stage III - determining the risk of developing professional laryngitis in teachers

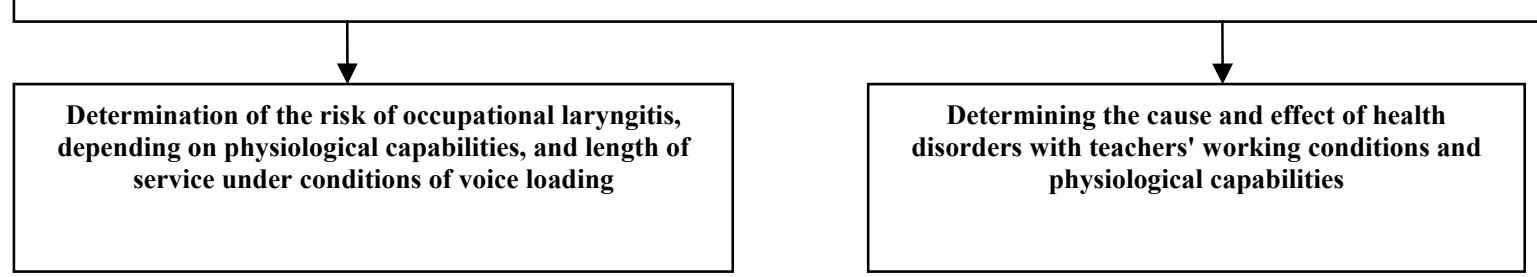

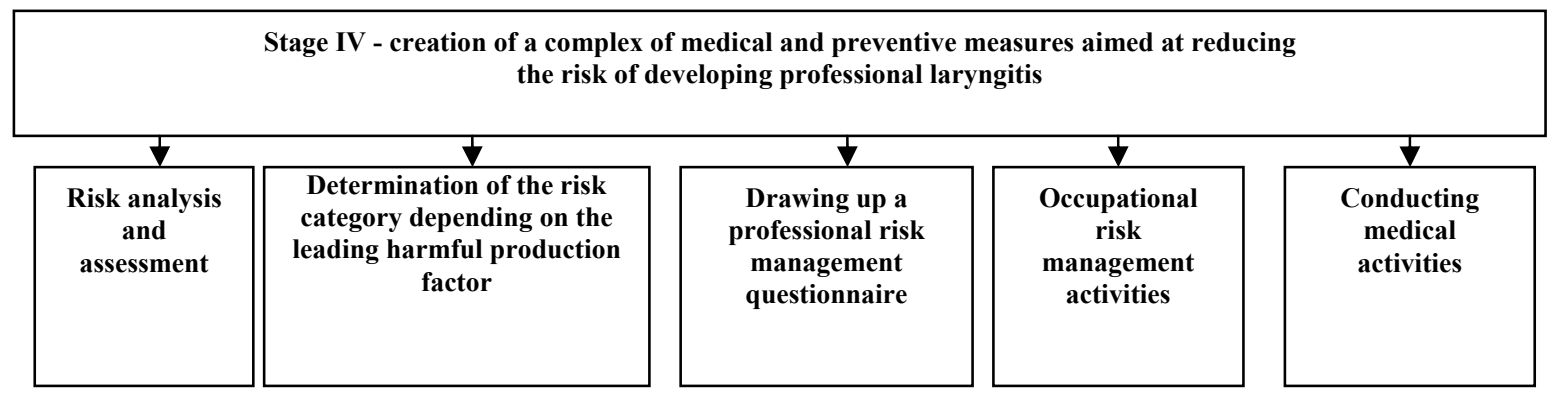

Stage V - development and implementation of preventive measures

Newsletter - 1

Fig. 1. Design, scopes and methods of research 


\section{General hygienic characteristic of teachers working conditions}

\begin{tabular}{|c|c|c|}
\hline $\mathbf{N}$ & Work environmental and labor factors & DSN-P № 248 \\
\hline 1 & Chemical & 2 \\
\hline 2 & Biological & 2 \\
\hline 3 & Physical: noise & 3.1 \\
\hline \multirow{3}{*}{4} & Microclimate: & \\
\hline & - warm period of a year & 3.1 \\
\hline & - cold period of a year & 3.1 \\
\hline 5 & Severity of labor & 2 \\
\hline 6 & Labor intensity & 3.3 \\
\hline 7 & General hygienic assessment & 3.3 \\
\hline
\end{tabular}

Structure and prevalence of general and occupational pathology of secondary school teachers. Chronic hypertrophic laryngitis is the most widespread pathology of the vocal apparatus in Kryvyi Rih (190.20 \pm 22.61$)$, making is $30.39 \%$ and chronic catarrhal laryngitis $(131.00 \pm 15.07$ cases) making $20.93 \%$ and in total it makes up $51.32 \%$ of the total number of diseases of the vocal apparatus of teachers.

Functional changes of the vocal apparatus include: functional dysphonia, phonasthenia, aphonia, hypotonic and hypertensive dysphonia, mutational dysphonia, hemorrhage into the vocal cords with temporary disability, which are the precursors of the occupational pathology. Organic changes of the vocal apparatus include - exfoliation of the mucous membranes of the vocal cords, postoperative laryngeal fibrosis, chronic catarrhal laryngitis, chronic hypertrophic laryngitis, chronic hyperplastic laryngitis, benign conditions on the larynx, Crick's nodes, preganglionic state, monochords, that lead to persistent disability and require prolonged outpatient and inpatient treatment.

Almost $70 \%$ occupational laryngitis cases are in the age group of 46-50 years, 51-55 years and 56-60 years.

The critical length of service influenced by voice stress is 10-19 years. Thus $60 \%$ of occupational laryngitis cases occur exactly during this period.
Determining the risk of functial dysphonia progression and the voice stress adaptive capacity of teachers.

The features of the adaptive reaction and level of emotional stress essentially influence the quality of blood circulation of the vocal cords of teachers. Adaptive potential index increasing above the norm by 0.1 c.u. leads to the risk of vocal cords damage by $27.0 \%$. Increasing of the teachers' adaptive capacity to the norm reduces the risk of damage of vocal cords by $45 \%$. At the same time, for the workers with voice stress length of service up to 20 years by $22 \%$, and for length of servise more than 30 years - by $51 \%$.

It is possible to reduce the number of circulatory disorders in the vocal cords by $50 \%$ and tone by $24.8 \%$ by decreasing of stress level (S) to normal (Table 2).

The dose of noise caused by the teacher's voice has a high correlation with occupational vocal cords disease, with functional vocal cords disorders.

Determination of acceptable duration (dose) of teachers' voice stress. The voice stress dose of $64.2 \pm 0.7 \mathrm{~dB}$ can be considered as safe (the risk of getting functional voice disorders is zero), $64.4 \pm 0.7 \mathrm{~dB}$ - as the borderline dose (the risk of functional dysphonia is 0.034 ), and $65.2 \pm 0.7 \mathrm{~dB}$ or more - as dangerous (the risk of functional dysphonia is 0.407 ). 
Risk of the vocal cords discoloration depending on the level of stress received

\begin{tabular}{l|c|c|c|c|c|c}
\hline $\begin{array}{c}\mathrm{S}-\text { level of } \\
\text { stress received, } \\
\text { relative units }\end{array}$ & Risk AR & Odds ratio OR & $\begin{array}{c}\text { Index } \\
\chi^{2}\end{array}$ & $\begin{array}{c}\text { Significance } \\
\text { p }\end{array}$ & $\begin{array}{c}\text { Criterion } \varphi \text { by } \\
\text { Cramer } \\
\text { K Chuprov }\end{array}$ & $\begin{array}{c}\text { Bound power according to } \\
\text { recommendations } \\
\text { Rea \& Parker }\end{array}$ \\
Less 1,12 & 0,22 & - & - & - & - \\
More 1,12 & 0,44 & $2,8 \pm 0,6$ & 3,0 & $\mathbf{p}<0,084$ & 0,236 \\
\hline
\end{tabular}

Determination of teachers' occupational vocal apparatus pathology progression risk indicates that after 20 years length of service in conditions of voice stress at risk of laryngeal disease progression teacher's age prevails the voice stress and its etiological percent of causes the incidence of the disease increases from $67.7 \%$ to $81.8 \%$. Therefore, an employee's age of $45.8 \pm 0.5$ and older is dangerous for the occupational laryngitis progression and requires a special approach of development and implementation of preventive measures aimed at maintaining of occupational health.

The highest chances of transition of functional (initial) vocal apparatus changes into organic ones (occupational laryngitis) influenced by the voice stress occur after 15-19 years length of service and more. After 25 years of experience, the chances diminish giving place to the overall aging of the body.

Substantiation of comprehensive system for managing the teacher's occupational laryngitis progression risk. Existing levels of occupational morbidity for chronic laryngitis, general morbidity among teachers of general education institutions that lead to disability and inability to fully engage in professional activity require the development and implementation of modern effective risk management measures to reduce morbidity, maintain high levels of working capacity and improve working conditions (Fig. 2).

Our modified complex of services for the treatment and prevention of functional disorders of the vocal apparatus relapses includes health aids (emoxipine, quercetin, stomatophyte A, instillations into the larynx of lemon essential oil, saline), physiotherapy treatment (massage of neck and collar zone with lavender oil, vibrational massage of the larynx and neck, coniferous and valerian baths (general) with hypo and hypertonic conditions, respectively, salt baths (foot) with hypertonic conditions, electrosleep), psychological (work with a psychologist), improvement of the general condition (spa treatment). The overall effectiveness of our complex of services ranges from $14.39 \%$ to $28.14 \%$, which indicates the high efficiency of the proposed measures to manage the recurrence of functional disorders of the vocal apparatus.

Our research indicated that increasing of the teachers' capacity to adapt to the norm reduces the risk of vocal cords damage by $45 \%$. In this case, teachers with length of service of up to 20 years by $22 \%$ and with more than 30 years - by $51 \%$. By reducing the stress level to normal the number of circulatory disorders cases in the vocal cords can be narrowed by $50 \%$ and the tone of the vocal cords by $24.8 \%$.

According to the calculated indicators in Kryvyi Rih, teachers lose 378 years DALY. According to a typical city lyceum - 11.96 DALY, and teacher with occupational laryngitis - 5.98 years DALY. We should add years lost with acute illness, which precedes occupational disability.

The duration of a healthy proportion of teaching experience is almost halved compared to the control group in the presence of occupational disease. The presence of functional dysphonia reduces the duration of healthy teaching experience by $26 \%$. In this case, the loss of a healthy proportion in the presence of occupational disease is five times more than in the comparison group, and with functional dysphonia - by 3.4 times.

Individualized preventive risk management measures increase the healthy life by 7.3 years and reduce the loss of healthy life years determined by the impact of voice activity by 7.1 years including physical health component (PH) by 4.5 and 4.3 , and the psychological health component (MH) by 10,3 and 10,1 years QALY respectively.

One dollar invested in risk management (prevention) of voice stress gives an additional 14 days of a healthy life. For the psychological component (MH) this indicant is 29 days QALY. The benefit of prevention outweighs the cost of it (utility-to-value ratio $>1$ ) and the benefit of it is 2.5 times more than treatment. 


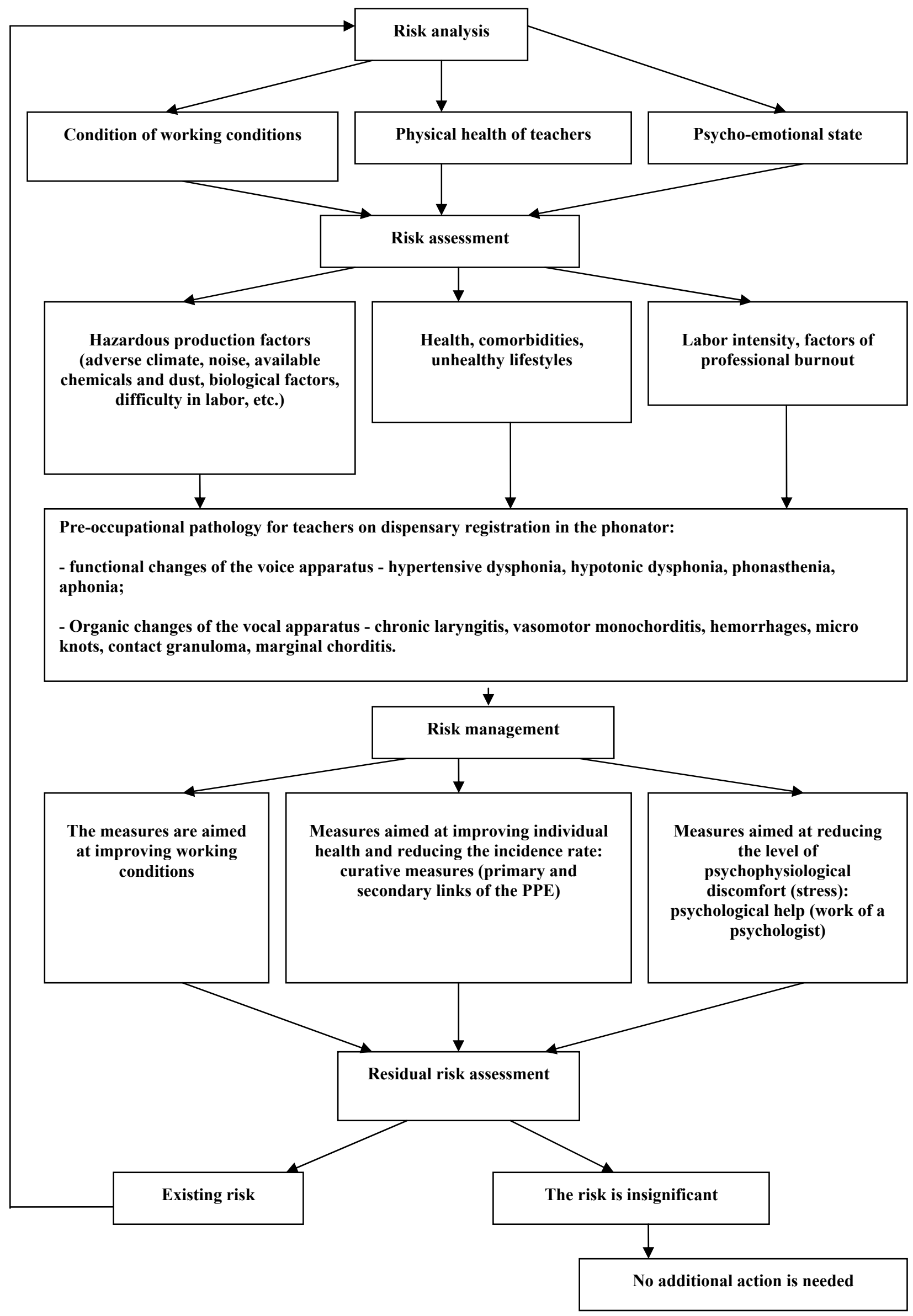

Fig. 2. General algorithm of assessment system and risk management of teachers' occupational laryngitis progression 


\section{CONCLUSION}

1. Teachers' working conditions are characterized by comprehensive impact of harmful production factors, which can reach $3^{\mathrm{d}}$ degree of $3^{\mathrm{d}}$ class of harm by indicators of intensity (according to calculated points 3,63$), 2^{\text {nd }}$ degree of 3 class of harm by vocal apparatus stressing, the total number of hours with the stressing of the vocal apparatus during the week $(27.52 \pm 3.54$ hours $), 1^{\text {st }}$ degree of 3 class of harm by equivalent noise level and adverse microclimate especially during the intermittent and cold seasons.

2. Chronic hypertrophic laryngitis is the most widespread teachers' pathology of the voce appara-

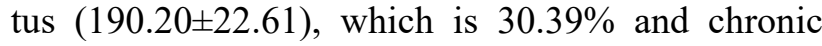
catarrhal laryngitis ( $131.00 \pm 15.07$ cases) also, which is $20.93 \%$ and summarizing it makes up $51.32 \%$ of the total number of diseases of the vocal apparatus of teachers. Almost 70\% occupational laryngitis cases are in the age group of 46-50 years, 51-55 years and 56-60 years. The critical length of service influenced by voice stress is $10-19$ years. Thus $60 \%$ of occupational laryngitis cases occur exactly during this period.

3. The length of service more than 20 years in conditions of voice stress increases the etiological percent of occupational pathology causes to $81.8 \%$. Therefore, an employee's age of $45.8 \pm 0.5$ and older is dangerous for the occupational laryngitis progression and requires a special approach of development and implementation of preventive measures aimed at maintaining of occupational health.

4. Based on the researche data the complex of scientifically-prevented and sanitary-prevented measures which increase the healthy life by 7.3 years and reduce the loss of healthy life years determined by the impact of voice activity by 7,1 years was developed. For physical health component (PH) by 4.5 and 4.3 , and the psychological health component $(\mathrm{MH})$ by allows the 10.3 and 10.1 years QALY respectively.

Conflict of interests. The authors declare no conflict of interest.

\section{REFERENCES}

1. Apykhtin KO, Latina HO. [The mode of work and hygienic working conditions of teachers in modern secondary schools]. Young Scientist. 2016;11.1(38.1):14. in Ukraine.

2. Vitsiuk AA. [Occupational diseases of teachers]. The world of medicine and biology. 2017;2(60):200-3. Ukrainian.

3. Kotova IA, Davoian OV. [Analysis and new directions in the work of the phoniatric service of Krivoy Rog]. Zhurnal vushnykh, nosovykh i horlovykh khvorob. 2016;3:77-78. Ukrainian.

4. Moskalyk OYe. [Functional disorders of voice in people with vocal professions, patients with allergic rhinosinusitis]. Zhurnal vushnykh, nosovykh i horlovykh khvorob. 2016;3:94-95. in Ukraine.

5. Stepanova YuYe, Gotovyakhina TV, Makhotkina NN. [The importance of timely diagnosis of diseases of the larynx at the initial examination by an otolaryngologist]. Meditsinskii sovet. 2018;20:58-60. Russian. doi: https://doi.org/10.21518/2079-701X-2018-20-58-64

6. Khollas T, Koyn D, Potter P. [Study of working conditions of school teachers of natural sciences]. Nauchno-metodicheskyi elektronnyi zhurnal «Kontsept». 2016;1:91-95. Russian.

URL: http://e-koncept.ru/2016/16019.htm
7. Baiba T. Epidemiology of Voice Disorders in Latvian School Teachers. Journal of Voice. 2017;31(4):508.e1508.e9. doi: https://doi.org/10.1016/j.jvoice.2016.10.014

8. Dan L, Bei W, Hui Y, Fei C, Jun L, Yanan X, Yitao Z, Yu Z, Jian Z, Haiyang W. A Comparative Study of the VHI-10 and the V-RQOL for Quality of Life Among Chinese Teachers With and Without Voice Disorders. Journal of Voice. 2017;31(4):509.e1-e6. doi: https://doi.org/10.1016/j.jvoice.2016.10.025

9. Natour YS, Sartawi AM, Al MO. et al. Emirati teachers' perceptions of voice handicap. Journal of Voice. 2016;30:378 (e13-20).

doi: https://doi.org/10.1016/j.jvoice.2015.04.001

10. Matthew H. Working Toward a Common Vocabulary: Reconciling the Terminology of Teachers of Singing, Voice Scientists, and Speech-Language Pathologists. Journal of Voice. 2017;31(6):647-48. doi: https://doi.org/10.1016/j.jvoice.2016.12.014

11. Seifpanahi S, Izadi F, Jamshidi A. Prevalence of voice disorders and associated risk factors in teachers and nonteachers in Iran. Journal of Voice. 2016;30:e19-e23. doi: https://doi.org/10.1016/j.jvoice.2015.05.019

12. Vitsiuk AA. [Teachers health as an actual problem of modern society]. Likars'ka sprava. 2018;1-2:178-81. Ukraine. doi: https://doi.org/10.31640/JVD.1-2.2018(30)

\section{СПИСОК ЛІТЕРАТУРИ}

1. Апихтін К. О., Латіна Г. О. Режим роботи та гігієнічні умови праці вчителів у сучасних загальноосвітніх навчальних закладах. Young Scientist. 2016. Nov. (T. 38.1, № 11.1). C. 1-4. 
2. Вицюк А. А. Профессиональные болезни педагогов. Мир медищинь и биологии. 2017. Т. 60, № 2. C. 200-203.

3. Котова И. А., Давоян О. В Анализ и новые направления в работе фониатрической службы Кривого Рога. Журнал вушних, носових $і$ горлових хвороб. 2016. № 3. C. 77-78.

4. Москалик О. Є. Функціональні розлади голосу у осіб голосомовних професій, хворих на алергічний риносинусит. Журнал вушних, носових $i$ горлових хвороб. 2016. № 3. С. 94-95.

5. Степанова Ю. Е., Готовяхина Т. В., Махоткина Н. Н. Важность своевременной диагностики заболеваний гортани при первичном осмотре врачом-отоларингологом. Медицинский совет. 2018. № 20. С. 58-60. DOI: https://doi.org/10.21518/2079-701X-2018-20-58-64

6. Холлас Т., Койн Д., Поттер П. Исследование условий труда школьных учителей естественных наук. Научно-методический электронный журнал «Кониепт». 2016. Январь. (№ 1). $\quad$ С. 91-95. URL: http://e-koncept.ru/2016/16019.htm

7. Baiba Trinite. Epidemiology of Voice Disorders in Latvian School Teachers. Journal of Voice. 2017. July. (Vol. 31， No. 4). P. 508.e1-508.e9. DOI: https://doi.org/10.1016/j.jvoice.2016.10.014
8. Comparative Study of the VHI-10 and the VRQOL for Quality of Life Among Chinese Teachers With and Without Voice Disorders / Lu Dan, et al. Journal of Voice. 2017. Vol. 31, No. 4. P. 509.e1509.e6. DOI: https://doi.org/10.1016/j.jvoice.2016.10.025

9. Emirati teachers' perceptions of voice handicap /Y. S. Natour et al. Journal of Voice. 2016. Vol. 30, No. 3. P. 378.

DOI: https://doi.org/10.1016/j.jvoice.2015.04.001

10. Matthew Hoch. Working Toward a Common Vocabulary: Reconciling the Terminology of Teachers of Singing, Voice Scientists, and Speech-Language Pathologists. Journal of Voice. 2017. Nov. (Vol. 31, No. 6). P. 647-648.

DOI: https://doi.org/10.1016/j.jvoice.2016.12.014

11. Seifpanahi S., Izadi F., Jamshidi A. A. Prevalence of voice disorders and associated risk factors in teachers and nonteachers in Iran. Journal of Voice. 2016. Vol. 30. P. e19-e23. DOI:

https://doi.org/10.1016/j.jvoice.2015.05.019

12. Vitsiuk A. A. Teachers health as an actual problem of modern society. Лікарська справа. 2018. № 1-2. C. 178-181.

DOI: https://doi.org/10.31640/JVD.1-2.2018(30)

Стаття надійшла до редакції 14.04.2020 